\title{
A Rare Case of Incidentally Detected Fused Supernumerary Kidney
}

\section{Nadir Görülen Insidental Füzyone Aksesuar Böbrek Olgusu}

\author{
iD Elif Gündoğdu, ID Emre Emekli \\ Eskişehir Osmangazi University Faculty of Medicine, Department of Radiology, Eskişehir, Turkiye
}

\begin{abstract}
Congenital renal anomalies are one of the most common congenital malformations. Supernumerary kidney is rare among these anomalies. A 78-year-old female patient, without urinary system complaints, was screened by abdominal computed tomography for staging of endometrial cancer. A supernumerary kidney fusing with the upper pole of right kidney was detected. Accessory kidney was located superomedial to the right kidney and was smaller than the normal kidney but there was no other pathology. In asymptomatic cases, follow-up is recommended due to increased risk of malignancy, for this reason, accurate diagnosis and follow-up are important.
\end{abstract}

Keywords: Supernumerary kidney, Congenital anomaly, Computed tomography

\section{$0 ̈ z$}

Konjenital böbrek anomalileri sık görülen konjenital anomalilerdendir. Bu anomaliler içerisinde ise en nadir saptananlardan biri aksesuar böbrektir. Üriner sistem yakınmaları olmayan 78 yaşındaki kadın hastaya endometriyum kanseri evrelemesi için abdominal bilgisayarlı tomografi çekimi gerçekleştirildi. İnsidental olarak sağ böbrek üst polüne füzyone aksesuar böbrek tespit edildi. Aksesuar böbrek sağ böbreğin süperomedialinde yerleşimliydi ve boyutu sağ böbrekten daha küçüktü. Ek patolojik bulgu mevcut değildi. Ancak asemptomatik olgularda artmış malignite riski nedeniyle doğru tanı konulması ve takip önem arz etmektedir.

Anahtar Kelimeler: Aksesuar böbrek, Konjenital anomali, Bilgisayarlı tomografi

\section{Introduction}

Congenital urinary system anomalies are the most common organ anomalies occurring in 3-6 per 1.000 live births (1). It constitutes about $1 / 3$ of all congenital anomalies (2). They may also be associated with syndromes or other organ system anomalies. For this reason, early diagnosis is very important. While symptomatic cases are correctly diagnosed by radiological investigations, asymptomatic cases are frequently detected incidentally in adulthood. Therefore, it is very important to know imaging findings for accurate diagnosis and patient management.

Classification of urinary system anomalies is done according to embryological development (1). Although unilateral renal agenesis is relatively common, supernumerary kidney is a very rare $(3,4)$. Less than 100 cases have been reported in the literature $(1,4,5)$. Most of the reported cases were symptomatic. We aimed to present an asymptomatic case of incidentally detected supernumerary kidney.

\section{Case Presentation}

A 78-year-old postmenopausal female patient with menorrhagia was diagnosed with endometrial carcinoma after biopsy. There were no urinary tract complaints in the history of the patient. Routine hematological and biochemical investigations were within the normal limits and urine analysis was normal. The CA-125 and CEA levels were high. Abdominopelvic computed tomography (CT) was performed for staging of endometrial carcinoma. 
Multidetector CT was performed (Toshiba, Aquilion 64, Japanese) after oral and intravenous administration of watersoluble iodinated contrast media. Heterogeneous, thickened endometrium and enlarged uterus were observed. Incidentally, the third kidney was observed to be fused with the upper pole of the right kidney (Figure 1). The supernumerary kidney was smaller than the native kidneys. No additional pathology was found in both native kidneys. The supernumerary kidney had a separate arterial supply originating from the abdominal aorta. CT angiography was not performed because the patient was asymptomatic and was not scheduled for renal surgery. The supernumerary kidney had its own collecting system and ureter (Figure 2). There was no complication during follow-up.

Written and informed consent for publishing this case report was obtained from the patient.

\section{Discussion}

Supernumerary kidney can be defined as an accessory kidney tissue with separate vascular supply and capsule $(1,3,6,7,8)$. The true incidence is unknown because it is a rare anomaly of the urinary system $(2,3,4,6,8)$. Less than 100 cases have been reported in the literature $(1,4,5)$. It is observed equally in both genders. The reported cases in the literature are generally asymptomatic adults aged $30-40$ years (5). The oldest patient reported in the literature was ours. Probably, she was not detected earlier because of being asymptomatic. Embryological development of the supernumerary kidney has not been fully understood. However, the mechanism can be abnormal division of the nephrogenic cord into two metanephric blastemas.

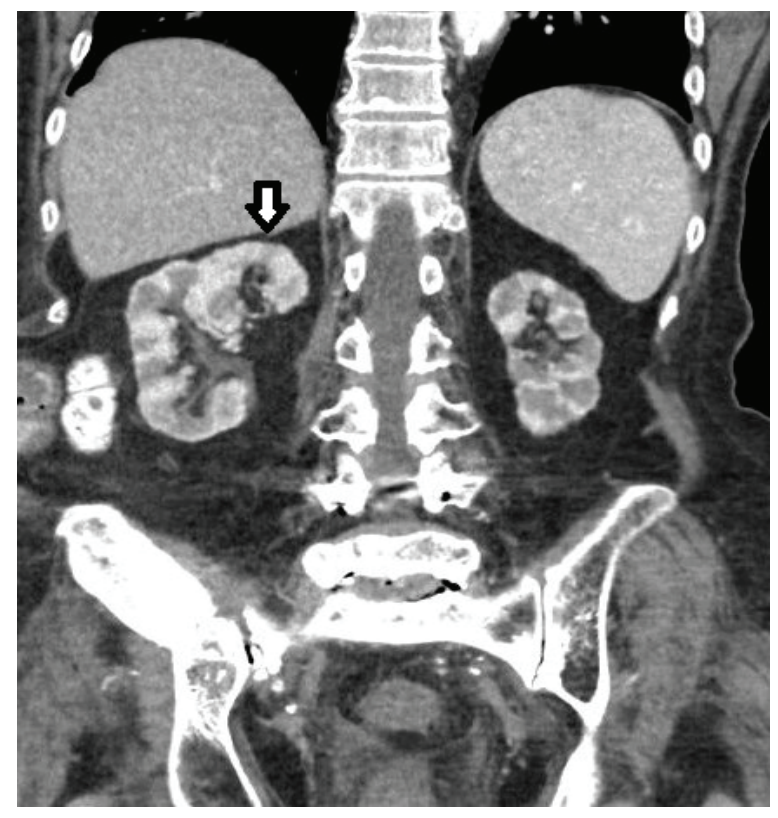

Figure 1. Coronal plane computed tomography shows supernumerary kidney just above the right kidney and fused with upper pole (arrow)
As a result, two kidneys are formed on the same side in association with a partially or completely duplicated ureteral bud $(3,4,5,6,8)$. Supernumerary kidneys are mostly observed to be caudally located on the left side of the abdomen $(1,2,3,7,8)$. Although supernumerary kidney is an accessory organ with a separate arterial supply, may not have its own collecting system. Supernumerary kidney is usually smaller than the normal kidney and is often functional $(1,3,8)$. It may be fused with the normal kidney $(2,7)$. In our case, the supernumerary kidney was on the right side of the abdomen. It was lying in anabnormally cranial and medial position. There was a separate collecting system, and artery originating from the abdominal aorta. It was fused with the upper pole of the right kidney. Supernumerary kidney can be diagnosed by various radiological imaging methods such as CT, endoscopic ultrasonography, ultrasonography (US) and magnetic resonance imaging $(1,3,6,7,8)$. In our case, the patient was diagnosed incidentally by CT. The duplex kidney should be considered in patients with a fused supernumerary kidney $(4,8)$. There is complete or incomplete duplication of the collecting system in the duplex kidney, but there is no anomaly in the parenchyma. Supernumerary kidney is an extra organ with separate vascular structures and capsule. It may be difficult to show separate artery and ureter on US. CT is superior to US and sufficient imaging modality in this condition.

Supernumerary kidney may be accompanied by various urogenital (ureterial atresia, vaginal atresia, horseshoe kidney anomaly, ectopic urethral opening, urethral duplication) or other organ system anomalies (imperforate anus, meningomyelocele, coarctation of the aorta, ventricular septal defect) $(1,3,6,7,8)$. No accompanying anomaly was detected in our case. It is important to know that various anomalies can accompany in these cases and to examine the patient for other anomalies (6).

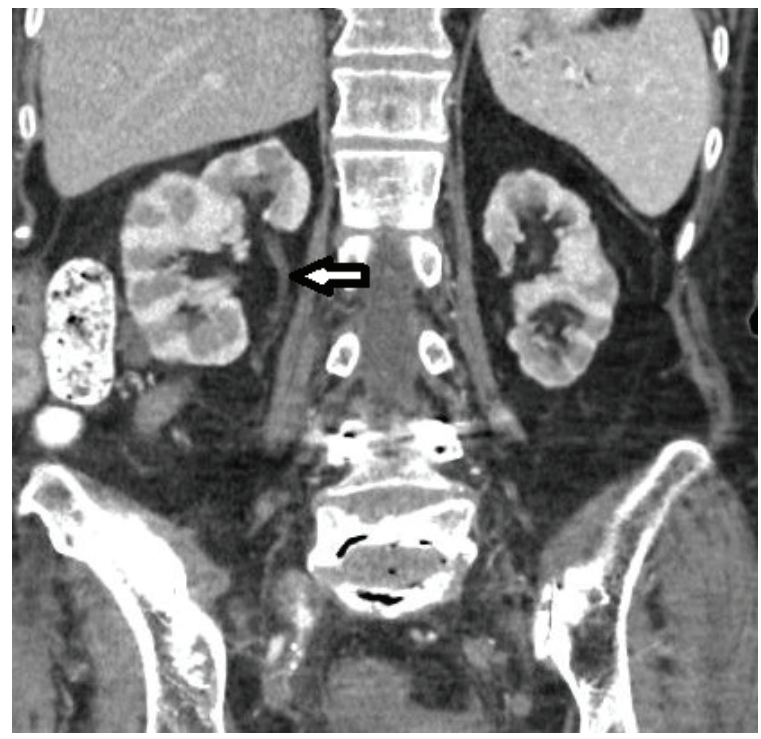

Figure 2. Coronal plane computed tomography shows separate collecting system of supernumerary right sided fused kidney (arrow) 
Supernumerary kidney is usually asymptomatic unless complicated. If complication occur, it usually presents with pain, fever, and palpable abdominal mass $(3,5,6,7)$. Approach to asymptomatic patients is follow-up, but surgery may be preferred if the kidney is nonfunctional $(3,4,6,8)$. Radiologic modalities should be used in the evaluation of arterial supply and collecting system in patients scheduled for surgery. In these cases, CT angiography and urography may be preferred.

\section{Ethics}

Informed Consent: Written and informed consent from the patient was obtained for publishing.

Peer-review: Externally and internally peer-reviewed.

\section{Authorship Contributions}

Concept: E.G., E.E., Design: E.G., E.E., Data Collection or Processing: E.E., Analysis or Interpretation: E.G., E.E., Literature Search: E.G., Writing: E.G., E.E.

Conflict of Interest: No conflict of interest was declared by the authors.
Financial Disclosure: The authors declared that this study received no financial support.

\section{References}

1. Ramanathan S, Kumar D, Khanna M., Al Heidous M, Sheikh A, Virmani V, Palaniappan Y. Multi-modality imaging review of congenital abnormalities of kidney and upper urinary tract. World J Radiol 2016;8:132.

2. Favorito LA, Morais AR. Evaluation of supernumerary kidney with fusion using magnetic resonance image. Int. Braz J Urol 2012;38:428-429.

3. Khalda E, Singh GN, Mandal AK, Kumar R. Unilateral supernumerary kidney with contra lateral hydronephrosis- a rare case report. Australas Med J 2014;7:213-217.

4. Sureka B, Mittal MK, Mittal A, Sinha M, Thukral BB. Supernumerary kidneys-- a rare anatomic variant. Surg Radiol Anat 2014; 36: 199-202.

5. Sen $\mathrm{V}$, Bozkurt $\mathrm{IH}$, Yonguc $\mathrm{T}$, Aydogdu 0, Basmaci I. A rare case of supernumerary fused and malrotated kidney. Int. Braz J Urol 2017;43:561562.

6. Jamshidian H, Tavakoli K, Salahshour F, Nabighadim A, Amini E. Supernumerary Kidney Associated with Horseshoe Malformation: A Case Report and Review of Literature. Urol Case Rep 2017;11:57-59.

7. Keskin S, Batur A, Keskin Z, Koc A, Firat Ozcan I. Bilateral supernumerary kidney: a very rare presentation. Iran J Radiol 2014;11:e11069.

8. Suresh J, Gnanasekaran N, Dev B. Fused supernumerary kidney. Radiol Case Rep 2011;6:552. 